\title{
Measuring Instrument Constructs of Return Factors for Green Office Building Investments Variables Using Rasch Measurement Model
}

\author{
Mona Isa1, a , Mazlan Abu Bakar², Ibrahim Sipan ${ }^{3}$, Mohamad Sufian Hasim ${ }^{4}$, Ahmad Ezanee Hashim ${ }^{5}$ and Mohd Khairul \\ Anuar Jalil 6 \\ ${ }^{1}$ Centre of Studies for Estate Management, Faculty of Architecture, Planning and Surveying, Universiti Teknologi Mara (UiTM) \\ ${ }^{2,4,5,6}$ Centre of Studies for Building Surveying, Faculty of Architecture, Planning and Surveying, Universiti Teknologi Mara (UiTM) \\ ${ }^{3}$ Department of Real Estate, Faculty of Geo-Information and Real Estate, Universiti Teknologi Malaysia
}

\begin{abstract}
This paper is a preliminary study on rationalising green office building investments in Malaysia. The aim of this paper is attempt to introduce the application of Rasch measurement model analysis to determine the validity and reliability of each construct in the questionnaire. In achieving this objective, a questionnaire survey was developed consists of 6 sections and a total of 106 responses were received from various investors who own and lease office buildings in Kuala Lumpur. The Rasch Measurement analysis is used to measure the quality control of item constructs in the instrument by measuring the specific objectivity within the same dimension, to reduce ambiguous measures, and a realistic estimation of precision and implicit quality. The Rasch analysis consists of the summary statistics, item unidimensionality and item measures. A result shows the items and respondent (person) reliability is at 0.91 and 0.95 respectively.
\end{abstract}

\section{Introduction}

Many studies have highlighted the benefits of going green, in line with the global campaign to support a sustainable development approach. Investment in green office buildings gives a more meaningful return from economic, social and environmental perspectives compared to investment in conventional office buildings. Since the concept of sustainability was introduced to investor, they have begun to divert their interest to environmentally-friendly buildings, particularly for the long-term benefits that can be derived. It is therefore appropriate to conduct a study and obtain more information to rationalise investment in green office buildings in Malaysia. In aiming to ascertain investor perception of return on investment (ROI) could serve to position this type of investment and provide guidelines to professionals and investors.

\section{The Rasch Measurement Model}

Rasch model analysis is the only tool available in social science research to determine whether the construct of the instrument is measuring the specific objectivity within the same dimension, minimising ambiguous measures, and that it is a realistic estimate of precision and implicit quality [1]. This model introduced a logarithm for the odds, or probabilistic value, to produce a measurement method with a logit function, dependant on the nature of

\footnotetext{
a Corresponding author: mazlanabubakar@yahoo.com.sg
}

the research. The logit is on a scale with an equal interval separation, and measurement starts at 0 , like other tools that establish a model to fit the research data. In this case, it establishes the hierarchical relationship between a person's response to an item and his or her level of construct measured by the scale [2].

Each item has its logit measure, which determines the level of difficulty of a question. Therefore, this study used the Rasch measurement model theorem to determine the credibility of the data and to further elaborate the Cronbach's alpha for data reliability and validity. This method has been more successful in envisioning and identifying investors that are highly interested in green office building investment, and the responses that were perceived as easy items, where respondents had opinions in common, if they invested in green office buildings. The Rasch model is a well-known method to convert ordinal data to interval data, to determine whether the latent traits or constructs are within the same dimension, and to provide data quality control before further analysis takes place [3]. Thus, the purpose of the Rasch measurement model is to produce a linear measure, to overcome missing data, to give an estimate of the precision and quality of the construct of the instrument, and to detect misfits or outliers. This is achieved by considering three parameters: point measure correlation $0.32<\mathrm{x}<0.8$, outfit mean squared $0.5<\mathrm{y}<1.5$, and outfit $\mathrm{z}$ standard $-2<\mathrm{z}<2$. It also provides a separable or 
independent measurement instrument for the parameters of the research object.

For the purposes of this study, the Winstep 15 Rasch programme was used for the data screening analysis. It produced tables and graphical outputs that enabled the fit of the data measurement to be checked. The summary statistics were derived based on the values of important indicators (Cronbach's alpha, item reliability, person reliability, person measure, and standard error), to determine whether the data were suitable for further analysis. The process of analysis involved four stages of data screening, consisting of summary statistics, unidimensionality and item measures.

\section{Instrument Development}

The development of specific research procedures that will result in empirical observations relies on the operationalization of variables. This research was developed based on variables derived from a conceptual framework that integrates all information to form several hypotheses to be tested, and to determine if the data supports them. The concepts were then operationally defined so that they could be measured, or operationalized, in order to be able to examine the behavioural dimensions, facets, or properties, denoted by the concept [4]. These were then translated into observable and measureable elements, to develop an index of measurement of the concept. Operationalization is the "process of precisely delineating how a construct is to be measured; that is, the variables which have to be specified in such manner as to be potentially observable or manipulated" [5]. Therefore, to assess the research hypotheses, all of the constructs in the questionnaire were defined operationally in the ways described below.

The survey questionnaire consisted of six sections, and each section was created with the purpose of finding answers to a different part of the research. Section A consisted of the demographic profile, which was further divided into the respondent's background and the organisation's background. The respondent's background included details about their gender, age, qualifications, position, and experience; while the organisation's background included the category of the company, company establishment, green ownership, total number of buildings owned, and level of participation in green office buildings.

Section B was to designed to obtain respondents' opinion on green office buildings, and whether they disagreed (1) or strongly agreed (5), using a Likert scale rating system. The items were designed based on the return on investment of green office buildings that relate to financial return, and social and environmental benefits. The purpose of this section was to identify the general opinion on green office building investment in Malaysia. Appendix 1 shows 13 questions that were designed to seek the general opinion of respondents on green office building investment. This was to investigate the general knowledge of the respondents on the research matter.

Section $C$ was the core area of the research and consisted of ROI factors and attributes, for example, financial return, cost savings, financial incentives, social benefits, and environmental benefits. This section attempted to obtain the opinions of the respondents on the perceived importance of return factors when investing in green office buildings. Each factor was broken down into few attributes, and this section contained 17 items. Appendix 2 , lists the items, consisting of financial return, cost saving, financial incentives, and social and environmental benefits, which form the ROI from green office buildings investment. The explanation of each item is defined clearly to ensure the respondents understood the research matter.

The second part of Section $\mathrm{C}$ consisted of the risks and building factors, which aimed to obtain the opinion of the respondents on the factors they perceived to be important in influencing returns (See appendix 3).

In section $\mathrm{D}$, the respondents were asked about the green office attributes that they perceived to be important in influencing the return of green office building investment. This section focused on the attributes that form a green office building as shown in Appendix 4.

Section E was intended to obtain the respondents' opinion on green office investment barriers, using a fivescale Likert rating system. The items consisted of 13 questions as shown in Appendix 5.

Section F investigated the willingness of respondents to participate in green office building investment. This section consisted of 6 items that rated the organisation's willingness to participate in green office building investment as shown in Appendix 6.

Much consideration was given to the development of all the items in the questionnaire. Too many items could have increased the amount of invalid data, while too few items may have affected the reliability and validity of the findings. The items in the questionnaire were selected to support the respective research constructs and research objectives. All of the items in this study questionnaire were adapted based on the combination of the literature review and previous studies. Based on work of current research interests, the appropriate items were selected from the previous researchers. A pilot test was undertaken, before the large-scale study was conducted. The format of the questionnaire and structure of each question was carefully designed with the objective with the objective of reducing, as much as possible, any biased answers from respondents. All of the questions were designed to be short, precise, and understandable. The format of the instrument was made simple, short, and comprehensible, and adaptable to statistical analysis $[6,7]$.

\section{Methodology}

The questionnaire was used to obtain information from respondents, who were identified as the investors. The population for this research consisted of the total number of office buildings owned by the three categories of office investors; namely, institutional investors, private individuals and property investor-developers in Klang Valley. The questionnaires were distributed using convenience sample to these three categories of investors. 
These investors are those who own and lease office buildings in the Federal Territory of Kuala Lumpur. The decision to choose the sample size based on the assumption that all these office buildings owned by the three categories of investors. Currently there are no established databases for institutional investors and private investors in the Klang Valley, except for property developers, so the sampling size was based on the total population of office buildings, tracking investors who currently own or lease an office building. The potential respondents hold high managerial positions within their respective organisations, their opinions can be considered strong enough and noteworthy for this study to determine the expected ROIs of organisation and the various factors influencing such returns.

\subsection{Response Rate}

All the data were collected from office building investors in Kuala Lumpur, who acted as respondents in the questionnaire survey. A breakdown of the questionnaire metrics is presented in Table 1 below.

Table 1. Breakdown of the questionnaire received.

\begin{tabular}{|l|c|}
\hline \multicolumn{1}{|c|}{ Data collection } & Number of questionnaires \\
\hline $\begin{array}{l}\text { Questionnaires distributed } \\
\text { (including pilot study) }\end{array}$ & 394 \\
\hline $\begin{array}{l}\text { Effective number of } \\
\text { questionnaires distributed }\end{array}$ & 394 \\
\hline $\begin{array}{l}\text { Questionnaire received - main } \\
\text { study }\end{array}$ & 106 (8 rejected) \\
\hline $\begin{array}{l}\text { Questionnaire received - pilot } \\
\text { study }\end{array}$ & 16 (4 rejected) \\
\hline $\begin{array}{l}\text { Total questionnaires } \\
\text { received }\end{array}$ & $\mathbf{1 3 0}$ (33\%) \\
\hline
\end{tabular}

In the two phases of the study, a total of 394 questionnaires were distributed, of which 130 were returned, but 12 could not be used. The total of 130 questionnaires received, represents a 33\% response rate. However, only 106 questionnaires are used for the main analysis. In conducting a questionnaire survey, a response rate from the population size is acceptable at $10 \%$ or less $[7$,$] . The requirement in achieving the minimum sample$ size for a population of 400 as suggested by Bartlett et al [8] for categorical data is 196.

However, this study managed to achieve only 106 responses. A few strategies were used to encourage responses from the top management including initiatives such as telephone call reminders, emails reminders and re-sending questionnaires to no-response locations by postage.

The main reasons for not responding to the questionnaires are time-related, such as the respondents were very busy with meetings and appointments, and were unable to fix appointments due to unexpected reasons. To justify further, the sample size very much depends on the type of respondents, and the more senior the position of the respondent in an organisation's hierarchy, the harder it is to persuade them to respond to a survey. Anseel, Choragwicka, Lievens, and Schollaert [9] identified the lowest response rate trend across respondent types ranked from executive positions and above. The distribution of responses from investors who own and rent office buildings in the Kuala Lumpur area is shown in Table 2.

Table 2. Distribution of office building and respondents' responses

\begin{tabular}{|l|c|c|c|c|c|}
\hline $\begin{array}{c}\text { Locati } \\
\text { on }\end{array}$ & $\begin{array}{c}\text { No. of } \\
\text { buildin } \\
\text { gs }\end{array}$ & $\begin{array}{c}\text { Frequen } \\
\text { cy }\end{array}$ & $\begin{array}{c}\text { Perce } \\
\text { nt }\end{array}$ & $\begin{array}{c}\text { Valid } \\
\text { perce } \\
\text { nt }\end{array}$ & $\begin{array}{c}\text { Cumulati } \\
\text { ve } \\
\text { percent }\end{array}$ \\
\hline $\begin{array}{l}\text { Golden } \\
\text { Triangl } \\
\text { e }\end{array}$ & 89 & 43 & 40.6 & 40.6 & 40.6 \\
\hline $\begin{array}{l}\text { Central } \\
\text { Busine } \\
\text { ss } \\
\text { District }\end{array}$ & 95 & 14 & 13.2 & 13.2 & 53.8 \\
\hline $\begin{array}{l}\text { Within } \\
\text { City } \\
\text { Centre }\end{array}$ & 132 & 25 & 23.6 & 23.6 & 77.4 \\
\hline $\begin{array}{l}\text { Suburb } \\
\text { an KL }\end{array}$ & 78 & 24 & 22.6 & 22.6 & 100.0 \\
\hline Total & 394 & 106 & 100.0 & 100.0 & \\
\hline
\end{tabular}

Table 2 shows that Golden Triangle recorded the highest percentages of responses from the respondents at 41 percent, followed by the City Centre ( 25 percent), Sub-urban areas in KL (24 percent) while the lowest response rate was in the Central Business District (14 percent). These frequencies show that the total number of the buildings within the location in the study area does not relate to the number of responses received from the respondents.

\section{Results and Discussion}

The first step in this research was to test whether the data obtained from the survey was statistically acceptable in terms of reliability and validity, and suitable for further analysis. At the same time, it was crucial to determine whether or not the constructs in the instrument were measuring the specific objectivity within the same dimension. To determine the requirement for data reliability and validity, Rasch measurement model analysis was conducted and the results of the survey were analysed in three ways to confirm data reliability and quality control, unidimensionality, and item measures and respondent-item fits. For the purposes of this research, the Rasch model is a suitable tool to achieve the abovementioned requirements.

The summary statistics for respondents (persons) and items (questions) are depicted in Tables 3 and 4 . The analysis was generated from 106 respondents, and consists of institutional investors, property developers, and private individuals, who own and rent office buildings within Kuala Lumpur. The study data would predictably fit the model, if all the indicators were in an accepted range. In summary, the statistics shown in Tables 3 and 4 contain a total of 8,479 data points, arising from 106 respondents on 80 items that were analysed. The generated response from the Winstep Rasch software showed the programme could obtain a statistical person 
measure and stable item calibrations. It yielded a chisquare value of $15,690.43$ with an 8,291 degree of freedom at $p=0.0000$. This indicated there was an association between the items.

Table 3. Summary of 106 measured respondents (persons)

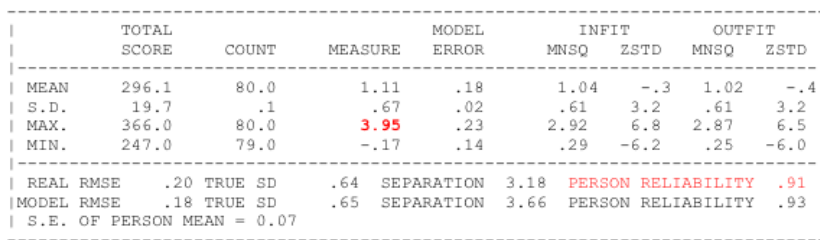

PERSON RAW SCORE-TO-MEASURE CORRELATION = .99

CRONBACH'S ALPHA (KR-20) PERSON RAW SCORE "TEST" RELIABILITY $=.91$

Table 4. Summary of 80 measured items

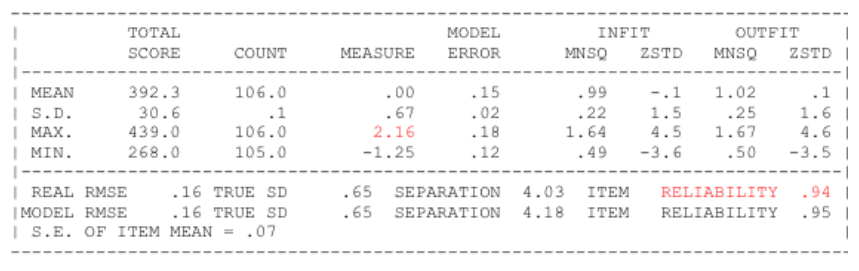

UMEAN $=.0000$ USCALE $=1.0000$

ITEM RAW SCORE-TO-MEASURE CORRELATION $=-.98$

8479 DATA POINTS. LOG-LIKELIHOOD CHI-SQUARE:

15690.43 with 8291 d.f. $p=.0000$, Global Root-Mean-Square

Residual (excluding extreme scores): .6442

The spread of person responses is from 3.95 to $(-0.17)=4.12$ logit. According to Fisher [10], person and item separated criterion for critical measures that are between 3 to 5 logit are considered good to excellent. A reliability of 0.91 and a Cronbach's alpha of 0.91 indicated highly reliable data, hence the data could be used for further analysis. For the questionnaire items, the summary of 80 measured items confirms a data spread from 2.16 to $(-1.25)=3.41$ logit, and a reliability of 0.94 , which are both good. The acceptable limits are 0.4 $<$ Acceptable Point Measure Correlation $<0.8$ and $0.5<$ Outfit Mean Square $<1.5$ and Outfit z-standardisation value $<2.0$.

The maximum item and respondent (person) measures are +2.16 logit and +3.95 logit respectively. Despite good reliability, a few difficult items (items that test the most capable persons or receive the least responses) need to be introduced where the gap is 1.79 (2.16 logit to 3.95 logit). The gap reflects the lack of items on difficult tasks constructed for the most capable investors in green office buildings investment. However, there are sufficient easy items, where the minimum item measure was -1.25 logit, in contrast to the least number of investors in agreement at -0.17 logit. The summary statistics describe the general overview of the complete data processed on items and persons' responses. Based on the literature, this data would require a second step, to determine whether or not the item measuring is within the same specific objectivity of the dimension, using unidimensionality analysis. This test identifies the contrasts and variances of the data, by checking groups of items sharing the same patterns of unexpectedness.

\subsection{Unidimensionality}

The assessment of unidimensionality is crucial to ensure the items in the instrument are measuring the specific objectivity within the same dimension. Rasch model analysis applies principal component analysis to the residuals, to determine whether the variance is measuring what is intended. For this research, the unidimensionality test is conducted to further investigate whether or not the items in the constructs are being measured consistently within the dimensions. This is the second step after examining the summary statistics. According to Linacre's recommendations for unidimensionality, the variance explained by measures must be above $40 \%$, with unexplained variance less than $15 \%$ in the first contrast, on the strength of at least 3 items. Conrad, Dennis, Riley, and Funk [11] also stated the unidimensionality requirement to be $40 \%$, which is consistent with Linacre, with above $30 \%$ is considered a moderate measurement dimension.

Table 5. Overall standardised residual variance (in eigenvalue units)

\begin{tabular}{|c|c|c|c|}
\hline Description & $\begin{array}{c}\text { Eigenvalue } \\
\text { units }\end{array}$ & $\begin{array}{c}\text { Empirical } \\
(\%)\end{array}$ & Modelled \\
\hline $\begin{array}{l}\text { Raw variance } \\
\text { explained by } \\
\text { measures }\end{array}$ & 27.2 & $25.3 \%$ & $26.2 \%$ \\
\hline $\begin{array}{l}\text { Raw } \\
\text { unexplained } \\
\text { variance (total) }\end{array}$ & 80.0 & $74.7 \%$ & $73.8 \%$ \\
\hline $\begin{array}{l}\text { Unexplained } \\
\text { variance in } 1^{\text {st }} \\
\text { contrast }\end{array}$ & 6.0 & $5.6 \%$ & \\
\hline $\begin{array}{l}\text { Unexplained } \\
\text { variance in } 2^{\text {nd }} \\
\text { contrast }\end{array}$ & $5.5 \%$ & $5.2 \%$ & \\
\hline $\begin{array}{l}\text { Unexplained } \\
\text { variance in } 3^{\text {rd }} \\
\text { contrast }\end{array}$ & 5.1 & $4.7 \%$ & \\
\hline $\begin{array}{l}\text { Unexplained } \\
\text { variance in } 4^{\text {th }} \\
\text { contrast }\end{array}$ & 4.4 & $4.1 \%$ & \\
\hline $\begin{array}{l}\text { Unexplained } \\
\text { variance in } 5^{\text {th }} \\
\text { contrast }\end{array}$ & 4.0 & $3.7 \%$ & \\
\hline
\end{tabular}

From the overall analysis of the items in Table 5, the raw variance explained by measures is $26.2 \%$, with unexplained variance in the first contrast of 6.0 and $5.6 \%$. This confirms that the raw variance explained by measures is below $40 \%$, with a high eigenvalue of 6.0 , indicating the items in the questionnaire are multidimensional constructs. The Winstep software is programmed to only measure a one dimension direction, therefore rectifying the issue of low percentages in 
modelled measures is achieved by analysing each construct separately.

Several tests had to be done to ensure that items belong to each construct. To address this issue, the unidimensionality analysis is carried out on each section in the questionnaire, which was divided into six subsections, as described in Table 6 overleaf.

Table 6. Standardised residual variance for each construct in the questionnaire

\begin{tabular}{|l|c|c|c|}
\hline Description & $\begin{array}{l}\text { Eigenvalue } \\
\text { units }\end{array}$ & Empirical & Modelled \\
\hline \multicolumn{3}{|c|}{ Section B: General opinion on green office building } \\
investment
\end{tabular}

\begin{tabular}{|l|l|l|l|}
\hline $\begin{array}{l}\text { Unexplained } \\
\text { variance in } 1^{\text {st }} \\
\text { contrast }\end{array}$ & 2.6 & $10.5 \%$ & $19.6 \%$ \\
\hline \multicolumn{3}{|c|}{ Section F: Willingness to invest in green office building } \\
investment
\end{tabular}

From Table 6, the variance in data explained by measures is within the modelled fit, ranging from $39 \%$ to $59 \%$. For questionnaire items, summaries of the 80 measured items, according to the order of measure, are shown in Appendices A1, A2, A3, A4, A5 and A6

\subsection{Item Measures}

The Rasch measurement model was used to check the precise position of each item. From item measures, we can identify the infit and outfit of each item by examining the mean square (MNSQ), z-standard (ZSTD), and pointmeasure correlation. From generated findings using the Winstep programme, each item position was ranked according to the level of response in the survey.

The items were ranked based on the highest and lowest number of persons selecting a particular response. The most important rating with the highest selection rate is ranked lowest, while items with the lowest number of selections and difficult to endorse are ranked highest. Therefore, the item ranked first is shown as the most difficult item to endorse. However, if the interpretation was made using SPSS by generating the mean score, the ranking would be in reverse order.

Based on the above item measures, in Appendix A1 item B1 failed Fisher's critical measures on ZSTD (infit and outfit) and point-measure correlation. However, the MNSQ value was good. Although items B7 and B8 failed to fit the ZSTD and B6 was on the point-measure correlation, these items still remained in the analysis. Item $B 1$ showed an unpredictable answer, while items $\mathrm{B} 7, \mathrm{~B} 8$, and B6, were still relevant because the value only affected one criterion. The items were retained in the analysis because of the need to provide a descriptive analysis to support the rationalisation of green office building investment in Malaysia. In Appendix A2, all items in Section $\mathrm{C}$ met the 3 indicator requirements in Fisher's critical measures. This was shown earlier in the summary statistics of the items in Table 4 - Summary of 80 measured items. Item C23 in Appendix A3 showed the item response was unpredictable with high outfit ZSTD, but the item was still relevant for further analysis. All other items were accommodated by the Rasch measurement model. All items are fits, except item D6, which has a high infit ZSTD for green office attributes, as shown in Appendix A4. However, the item was relevant for further analysis. 
It can be seen from Appendix A5, that all items fit the model dimension. Based on the above, the items were revised for more precise constructs before further analysis using SPSS took place. The number of removed items was minimal, and this was already expected because the findings from the summary statistics showed very good reliability of the items at 0.94 , as shown in Table 4.

\section{Conclusions}

The Rasch model analysis confirmed that all the items in the questionnaire constructs were statistically reliable and valid for further analysis, and each item was measuring the specific objectivity within the same dimension. The results were also supported by Cronbach's alpha test at 0.91, which showed excellent reliability for persons-items data. The application of the Rasch measurement model aims to provide a new dimension and technique, to examine the data reliability and validity of the instrument used for this research.

\section{References}

1. Azrilah Abdul Aziz. Rasch Model Fundamentals: Scale Construct and Measurement Structure: Integrated Advance Planning Sdn Bhd. (2011)

2. Edelen, M. O., \& Reeve, B. B. Applying item response theory (IRT) modelling to questionaire development, evaluation and refinement. Quality LIfe Research, 16, 5-18. doi: 10.1007/s11136-0079198-0 (2007)

3. Bond, T. G., \& Fox, C. M. Applying the Rasch Model: Fundamental Measurement In The Human Sceince: Lawrence Erlbaum. (2007)

4. Sekaran, U., \& Bougie, R. Research Methods for BUsiness: A skill-building approach (6th Edition ed.): Wiley. (2010)

5. Joseph F. Hair, J., Black, W. C., Babin, B. J., \& Anderson, R. E. Multivariate Data Analysis: A Global Perspective: Pearson Prentice Hall. (2010)

6. Bryman, A., \& Bell, E. Business Research Methods. New York: Oxford University Press. (2011)

7. Collis, J., \& Hussey, R. Business Research: A practical guide for undergraduate and postgraduate students. London, United Kingdom: Palgrave Macmillan. (2009)

8. James E. Bartlett, I., Kortlik, J. W., \& Hinggins, C. C. Organisational Research: Determining Appropriate Sample Size in Survey Research. Information Technology, Learning and Performance Journal, 19(No.1), 43-50. (2001)

9. Anseel, F., Choragwicka, B., Lievens, F., \& Schollaert, E. Response Rates in Organizational Science, 1995-2008: A Meta-analytic Review and Guidelines for Survey Researchers. Journal of Business Psychology (25), 335-349. doi: DOI 10.1007/s10869-010-9157-6 (2010)

10. Sayce, S., Ellison, L., \& Parnell, P. Understanding investment drivers for UK sustainable property.
Building Research \& Information, 35(6), 629-643. (2007)

11. Conrad, K. J., Conrad, K. H., Dennis, M. L., Riley, B. B., \& Funk, R. Validation of the Behavioural Complexity Scale (BCS) to the Rasch Model, GAIN Methods Report 1.2. 2012, from www.gaincc.org (2011) 


\section{APPENDIX A1}

Item Measures of Section B

\begin{tabular}{|c|c|c|c|c|c|c|c|c|c|c|c|}
\hline \multirow[b]{2}{*}{$\begin{array}{l}\underset{\Xi}{\Xi} \\
\stackrel{\Xi}{0} \\
z\end{array}$} & & \multirow[b]{2}{*}{$\stackrel{\Xi}{\Xi}$} & \multirow[b]{2}{*}{ 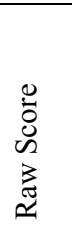 } & \multirow[b]{2}{*}{$\vec{\Xi}$} & \multirow[b]{2}{*}{ 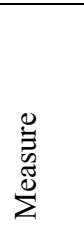 } & \multirow[b]{2}{*}{ 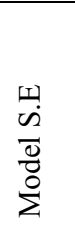 } & \multicolumn{2}{|c|}{ Infit } & \multicolumn{2}{|c|}{ Outfit } & \multirow[b]{2}{*}{ 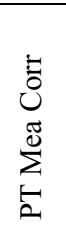 } \\
\hline & & & & & & & $\begin{array}{l}O \\
\mathscr{L} \\
\Sigma\end{array}$ & $\stackrel{\theta}{\mathcal{N}}$ & $\begin{array}{l}O \\
\mathscr{Z} \\
z\end{array}$ & $\stackrel{\ominus}{\stackrel{\theta}{N}}$ & \\
\hline \multicolumn{12}{|c|}{ Section B: General Opinion on Green Office Building Investment } \\
\hline B1 & 1 & Willingness & 347 & 106 & 1.29 & 0.14 & 1.35 & 2.3 & 1.43 & 2.7 & 0.38 \\
\hline $\mathrm{B} 2$ & 7 & Yield & 394 & 106 & 0.18 & 0.17 & 0.84 & -1.0 & 0.85 & -.9 & 0.35 \\
\hline B3 & 8 & Rental & 396 & 106 & 0.12 & 0.17 & 0.83 & -1.0 & 0.87 & 0.42 & 0.42 \\
\hline B4 & 5 & Tenant & 386 & 106 & 0.40 & 0.16 & 0.91 & -.50 & .99 & .0 & 0.47 \\
\hline B5 & 9 & Image & 410 & 106 & -.32 & .18 & 1.19 & 1.1 & 1.16 & .9 & 0.53 \\
\hline B6 & 4 & Occupancy & 376 & 106 & 0.66 & 0.16 & 0.98 & -.10 & 1.25 & 1.5 & 0.23 \\
\hline B7 & 12 & Energy & 434 & 106 & -1.23 & .20 & .78 & -1.3 & .77 & -1.3 & 0.48 \\
\hline B8 & 3 & Accessibility & 371 & 106 & 0.77 & 0.15 & 1.21 & 1.4 & 1.40 & 2.4 & 0.55 \\
\hline B9 & 13 & Environmentally friendly & 439 & 106 & -1.44 & 0.20 & 0.63 & -2.5 & 0.62 & -2.5 & 0.57 \\
\hline $\mathrm{B} 10$ & 10 & $\begin{array}{l}\text { Better working } \\
\text { enviroment }\end{array}$ & 419 & 106 & -.64 & .19 & .92 & -.4 & .91 & -.5 & 0.55 \\
\hline B11 & 11 & Cost & 423 & 106 & -.79 & 0.20 & 1.16 & .9 & 1.03 & .30 & 0.51 \\
\hline B12 & 2 & Low mainatenance & 370 & 106 & 0.80 & 0.15 & 1.16 & 1.1 & 1.25 & 1.6 & 0.44 \\
\hline B13 & 6 & Marketability & 393 & 106 & .21 & .17 & .66 & -2.3 & .67 & -2.2 & 0.63 \\
\hline
\end{tabular}

\section{APPENDIX A2}

Item Measures Of Section C

\begin{tabular}{|c|c|c|c|c|c|c|c|c|c|c|c|}
\hline \multirow[b]{2}{*}{$\begin{array}{l}\underset{\Xi}{\Xi} \\
\stackrel{\Xi}{Z} \\
\text { z }\end{array}$} & \multirow[b]{2}{*}{ 害 } & \multirow[b]{2}{*}{ Е } & \multirow[b]{2}{*}{ 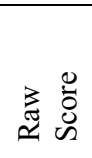 } & \multirow[b]{2}{*}{ 荂 } & \multirow[b]{2}{*}{$\begin{array}{l}\stackrel{0}{\Xi} \\
\stackrel{\Xi}{\Xi} \\
\stackrel{\Xi}{\Xi}\end{array}$} & \multirow[b]{2}{*}{$\begin{array}{l}\overrightarrow{0} \\
\stackrel{0}{0}=1 \\
\dot{\Sigma}\end{array}$} & \multicolumn{2}{|c|}{ Infit } & \multicolumn{2}{|c|}{ Outfit } & \multirow[b]{2}{*}{$\sum_{0}^{\infty}$} \\
\hline & & & & & & & MNSQ & ZSTD & MNSQ & ZSTD & \\
\hline \multicolumn{12}{|c|}{ Section C: Returns Factors of Green Office Building Investment } \\
\hline $\mathrm{C} 1$ & 14 & Capital & 415 & 106 & -0.55 & 0.18 & 1.08 & 0.5 & 1.13 & .8 & .40 \\
\hline $\mathrm{C} 2$ & 10 & Rental & 398 & 106 & -.05 & .16 & 1.31 & 1.9 & 1.35 & 2.1 & .41 \\
\hline $\mathrm{C} 3$ & 9 & Occupancy & 396 & 106 & .00 & .16 & 1.17 & 1.1 & 1.17 & 1.1 & .46 \\
\hline C4 & 7 & Yield & 383 & 106 & .33 & .15 & .75 & -1.8 & .8 & -1.4 & .52 \\
\hline $\mathrm{C} 5$ & 17 & Energy & 438 & 106 & -1.36 & .20 & .85 & -.9 & .86 & -.8 & .50 \\
\hline C6 & 16 & Water & 428 & 106 & -.99 & .19 & 1.06 & .4 & 1.12 & .7 & .42 \\
\hline $\mathrm{C} 7$ & 15 & Operational & 423 & 106 & -.81 & .19 & 1.20 & 1.1 & 1.22 & 1.3 & .43 \\
\hline $\mathrm{C} 8$ & 2 & Insuran & 367 & 106 & .69 & .15 & 1.02 & .2 & 1.14 & 1.0 & .50 \\
\hline C9 & 8 & Green tax & 395 & 106 & .03 & .16 & .96 & -.2 & 1.05 & .4 & .48 \\
\hline $\mathrm{C} 10$ & 12 & $\begin{array}{l}\text { Green } \\
\text { incentives }\end{array}$ & 403 & 106 & -.19 & .17 & .84 & -1.0 & .80 & -1.3 & .57 \\
\hline C11 & 1 & CSR & 349 & 106 & 1.06 & .14 & .72 & -2.3 & .76 & -1.9 & .68 \\
\hline $\mathrm{C} 12$ & 4 & Image & 373 & 106 & .56 & .15 & .94 & -.4 & .94 & -.4 & .63 \\
\hline $\mathrm{C} 13$ & 6 & Branding & 377 & 106 & .47 & .15 & 1.10 & .8 & 1.23 & 1.5 & .49 \\
\hline C14 & 11 & Satisfaction & 399 & 106 &.-08 & .17 & .74 & -1.9 & .70 & -2.1 & .70 \\
\hline C15 & 13 & Productivity & 404 & 106 & -.22 & .17 & .82 & -1.2 & .80 & -1.3 & .61 \\
\hline $\mathrm{C} 16$ & 3 & Sustainability & 371 & 106 & .60 & .15 & 1.27 & 1.9 & 1.31 & 2.1 & .56 \\
\hline C17 & 5 & $\begin{array}{l}\text { Minimise } \\
\text { pollution }\end{array}$ & 376 & 106 & 0.49 & .15 & 1.04 & .4 & 1.04 & .4 & .54 \\
\hline
\end{tabular}




\section{APPENDIX A3}

\section{Item Measures Of Section C, Part 2}

\begin{tabular}{|c|c|c|c|c|c|c|c|c|c|c|c|}
\hline \multirow[b]{2}{*}{ 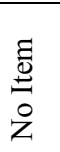 } & \multirow[b]{2}{*}{ 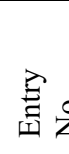 } & \multirow[b]{2}{*}{ 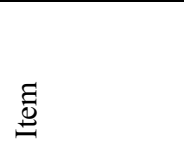 } & \multirow[b]{2}{*}{ 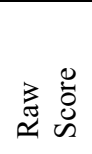 } & \multirow[b]{2}{*}{$\begin{array}{l}\vec{\Xi} \\
\text { ¿̊ }\end{array}$} & \multirow[b]{2}{*}{$\begin{array}{l}\stackrel{0}{\Xi} \\
\text { 荧 } \\
\sum\end{array}$} & \multirow[b]{2}{*}{ 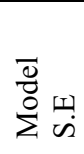 } & \multicolumn{2}{|c|}{ Infit } & \multicolumn{2}{|c|}{ Outfit } & \multirow[b]{2}{*}{$\sum_{E}^{\mathbb{E}}$} \\
\hline & & & & & & & MNSQ & ZSTD & MNSQ & ZSTD & \\
\hline \multicolumn{12}{|c|}{ Section C: Factors Affecting Returns in Green Office Building Investment } \\
\hline $\mathrm{C} 18$ & 2 & Economic & 367 & 106 & .66 & .16 & .96 & -.3 & .93 & -.4 & .60 \\
\hline C19 & 5 & Govern & 383 & 106 & .28 & .16 & .83 & -1.2 & .76 & -1.6 & .69 \\
\hline $\mathrm{C} 20$ & 1 & Surrounding & 367 & 106 & .68 & .16 & .77 & -1.8 & .91 & -.6 & .64 \\
\hline $\mathrm{C} 21$ & 3 & Physical & 374 & 106 & .51 & .16 & 1.01 & .1 & 1.01 & .1 & .61 \\
\hline $\mathrm{C} 22$ & 10 & Location & 416 & 106 & -.78 & .20 & 1.34 & 1.8 & 1.29 & 1.5 & .48 \\
\hline $\mathrm{C} 23$ & 6 & Building & 396 & 106 & -.09 & .17 & 1.22 & 1.4 & 1.40 & 2.2 & .48 \\
\hline $\mathrm{C} 24$ & 7 & Building & 396 & 106 & -.09 & .17 & .93 & -.4 & .87 & -.7 & .61 \\
\hline $\mathrm{C} 25$ & 4 & Type & 374 & 106 & .51 & .16 & 1.15 & 1.1 & 1.18 & 1.2 & .57 \\
\hline $\mathrm{C} 26$ & 8 & Property Mgt & 397 & 106 & -.13 & .18 & 1.06 & .5 & 1.05 & .3 & .58 \\
\hline $\mathrm{C} 27$ & 9 & Building & 415 & 106 & -.74 & .19 & 1.00 & .1 & .97 & -.1 & .50 \\
\hline $\mathrm{C} 28$ & 11 & Facility & 415 & 106 & -.81 & .20 & .68 & -.20 & .66 & -2.0 & .56 \\
\hline
\end{tabular}

\section{APPENDIX A4}

\section{Item Measures Of Section D: Green Office Building Attributes}

\begin{tabular}{|c|c|c|c|c|c|c|c|c|c|c|c|}
\hline \multirow[b]{2}{*}{$\begin{array}{l}\text { Eี } \\
\stackrel{\Xi}{0} \\
0 \\
z\end{array}$} & \multirow[b]{2}{*}{ 㲄 } & \multirow[b]{2}{*}{$\stackrel{\Xi}{\Xi}$} & \multirow[b]{2}{*}{ 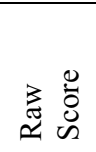 } & \multirow[b]{2}{*}{$\begin{array}{l}\vec{\Xi} \\
0\end{array}$} & \multirow[b]{2}{*}{ 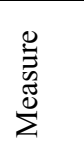 } & \multirow[b]{2}{*}{ 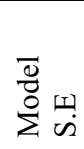 } & \multicolumn{2}{|c|}{ Infit } & \multicolumn{2}{|c|}{ Outfit } & \multirow[b]{2}{*}{ 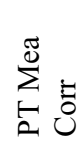 } \\
\hline & & & & & & & MNSQ & ZSTD & MNSQ & ZSTD & \\
\hline \multicolumn{12}{|c|}{ Section D: Green Attributes of Green Office Building Investment } \\
\hline D1 & 18 & Renewa & 435 & 106 & -1.02 & .22 & 1.35 & 1.8 & 1.16 & .8 & .43 \\
\hline $\mathrm{D} 2$ & 11 & Electricity & 418 & 106 & -.26 & 20 & 1.35 & 1.8 & 1.19 & 1.0 & .53 \\
\hline D3 & 17 & Light & 431 & 106 & -.84 & .22 & .62 & -2.3 & .78 & -1.1 & .57 \\
\hline D4 & 19 & Cooling & 438 & 106 & -1.17 & .22 & .73 & -1.6 & .66 & -1.8 & .57 \\
\hline D5 & 20 & Effect & 439 & 106 & -1.22 & 0.22 & 0.97 & -.1 & .97 & -.1 & .54 \\
\hline D6 & 5 & $\begin{array}{l}\text { Rain } \\
\text { Conservation }\end{array}$ & 389 & 106 & .75 & .17 & 1.39 & 2.3 & 1.55 & 2.7 & .66 \\
\hline D7 & 8 & High & 399 & 106 & .44 & .18 & .84 & -1.0 & .84 & -.9 & .65 \\
\hline D8 & 14 & Air Quality & 423 & 106 & -.47 & .21 & 1.03 & .2 & .83 & -.8 & .62 \\
\hline D9 & 12 & Thermal & 418 & 106 & -.26 & .20 & .76 & -1.4 & .58 & -2.4 & .66 \\
\hline D10 & 15 & Lighting & 423 & 106 & -.47 & .21 & 1.00 & .1 & .78 & -1.1 & .62 \\
\hline D11 & 16 & Heal & 430 & 106 & -.79 & .22 & .58 & -2.6 & .45 & -3.3 & .68 \\
\hline D12 & 2 & Site & 377 & 106 & 1.09 & .16 & .97 & -.2 & 1.19 & 1.1 & .61 \\
\hline D13 & 4 & Construction & 385 & 106 & .87 & .17 & .94 & -.3 & 1.1 & .6 & .6 \\
\hline D14 & 7 & Accessibility & 398 & 106 & .47 & .18 & 1.27 & 1.6 & 1.36 & 1.8 & .49 \\
\hline D15 & 13 & Building & 418 & 106 & -.26 & .20 & .89 & -.5 & .82 & -.9 & .59 \\
\hline D16 & 1 & Recycling & 364 & 106 & 1.41 & .16 & 1.03 & .3 & 1.32 & 1.9 & .51 \\
\hline D17 & 9 & Waste & 402 & 106 & .34 & .18 & .90 & -.6 & .88 & -.6 & .56 \\
\hline D18 & 6 & Green & 393 & 106 & .63 & .18 & .90 & -.6 & .99 & .0 & .55 \\
\hline D19 & 10 & Innovation & 417 & 106 & -.22 & .20 & 1.33 & 1.7 & 1.27 & 1.3 & .53 \\
\hline $\mathrm{D} 20$ & 3 & Green & 380 & 106 & 1.00 & .16 & 1.03 & .2 & 1.18 & 1.1 & .52 \\
\hline
\end{tabular}




\section{APPENDIX A5}

Item Measures Of Section E

\begin{tabular}{|c|c|c|c|c|c|c|c|c|c|c|c|}
\hline \multirow[b]{2}{*}{ 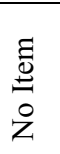 } & \multirow[b]{2}{*}{ 氙 } & \multirow[b]{2}{*}{$\stackrel{\Xi}{\Xi}$} & \multirow[b]{2}{*}{ 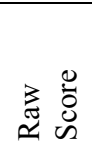 } & \multirow[b]{2}{*}{$\vec{\Xi}$} & \multirow[b]{2}{*}{$\begin{array}{l}\stackrel{0}{\Xi} \\
\stackrel{\Xi}{\Xi} \\
\stackrel{\Xi}{\Xi}\end{array}$} & \multirow[b]{2}{*}{ 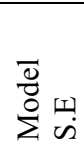 } & \multicolumn{2}{|c|}{ Infit } & \multicolumn{2}{|c|}{ Outfit } & \multirow[b]{2}{*}{$\sum_{\omega}^{\mathbb{E}}$} \\
\hline & & & & & & & MNSQ & ZSTD & MNSQ & ZSTD & \\
\hline \multicolumn{12}{|c|}{ Section D: Green Attributes of Green Office Building Investment } \\
\hline E1 & 1 & Higher capital & 268 & 106 & 1.87 & .14 & 1.02 & .2 & .99 & .0 & .56 \\
\hline E2 & 2 & No necessity & 292 & 106 & 1.43 & .13 & 1.21 & 1.6 & 1.23 & 1.7 & .57 \\
\hline E3 & 13 & No faith & 422 & 106 & -1.29 & .18 & 1.57 & 2.9 & 1.57 & 2.8 & .31 \\
\hline E4 & 4 & $\begin{array}{l}\text { Onerous } \\
\text { procedure }\end{array}$ & 346 & 106 & .49 & .13 & .67 & -3.1 & .76 & -2.0 & .57 \\
\hline E5 & 3 & $\begin{array}{l}\text { Unsure } \\
\text { benefits }\end{array}$ & 315 & 106 & 1.03 & .13 & 1.02 & .2 & .98 & -.1 & .64 \\
\hline E6 & 9 & $\begin{array}{l}\text { Public } \\
\text { encourageme } \\
\text { nt }\end{array}$ & 395 & 106 & -.53 & .16 & .89 & -.7 & .89 & -.7 & .56 \\
\hline E7 & 12 & $\begin{array}{l}\text { Lack best } \\
\text { practices }\end{array}$ & 406 & 106 & -.81 & .17 & .85 & -.9 & .85 & -.9 & .45 \\
\hline E8 & 6 & $\begin{array}{l}\text { Lack } \\
\text { knowledge }\end{array}$ & 381 & 106 & -.20 & .15 & .94 & -.3 & 1.10 & .7 & .56 \\
\hline E9 & 5 & Absence & 376 & 106 & -.09 & .15 & .89 & -.8 & 1.01 & .1 & .58 \\
\hline E10 & 10 & $\begin{array}{l}\text { No legal } \\
\text { requirement }\end{array}$ & 397 & 106 & -.58 & .16 & 1.05 & .4 & 1.03 & .2 & .46 \\
\hline E11 & 7 & Insufficient & 384 & 106 & -.27 & .15 & .90 & -.6 & 1.00 & .1 & .44 \\
\hline E12 & 8 & $\begin{array}{l}\text { Insufficient } \\
\text { tenant } \\
\text { demand }\end{array}$ & 390 & 106 & -.41 & .15 & 1.03 & .3 & 1.13 & .9 & .35 \\
\hline E13 & 11 & $\begin{array}{l}\text { Lack property } \\
\text { performance }\end{array}$ & 400 & 106 & -.65 & .16 & .76 & -1.6 & .76 & -1.6 & .60 \\
\hline
\end{tabular}

\section{APPENDIX A6}

\section{Item Measures Of Section F}

\begin{tabular}{|c|c|c|c|c|c|c|c|c|c|c|c|}
\hline \multirow[b]{2}{*}{$\begin{array}{l}\underset{\Xi}{\Xi} \\
\stackrel{\Xi}{\circ} \\
Z\end{array}$} & \multirow[b]{2}{*}{ 氞 } & \multirow[b]{2}{*}{$\stackrel{\Xi}{\Xi}$} & \multirow[b]{2}{*}{ 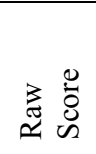 } & \multirow[b]{2}{*}{ 䒠 } & \multirow[b]{2}{*}{$\begin{array}{l}\stackrel{0}{\Xi} \\
\stackrel{\Xi}{\Xi} \\
\stackrel{\Xi}{\Sigma}\end{array}$} & \multirow[b]{2}{*}{ 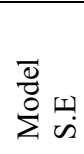 } & \multicolumn{2}{|c|}{ Infit } & \multicolumn{2}{|c|}{ Outfit } & \multirow[b]{2}{*}{$\sum_{E}^{\mathbb{E}}$} \\
\hline & & & & & & & MNSQ & ZSTD & MNSQ & ZSTD & \\
\hline \multicolumn{12}{|c|}{ Section F: Willingness To Invest In Green Office Building } \\
\hline F1 & 2 & Participate & 379 & 106 & .12 & .23 & 1.27 & 1.7 & 1.33 & 1.6 & .65 \\
\hline F2 & 1 & Purchase & 346 & 106 & 1.66 & .21 & 1.04 & .3 & 1.23 & 1.4 & .74 \\
\hline F3 & 3 & Occupy & 376 & 106 & .11 & .23 & 1.08 & .5 & .96 & -.1 & .73 \\
\hline F4 & 4 & Dissemination & 382 & 106 & -.04 & .23 & 1.08 & .5 & .96 & -.1 & .77 \\
\hline F5 & 6 & $\begin{array}{l}\text { Take } \\
\text { opportunity }\end{array}$ & 399 & 106 & -.95 & .23 & .71 & -2.0 & .64 & -2.1 & .73 \\
\hline F6 & 5 & $\begin{array}{l}\text { Implementati } \\
\text { on }\end{array}$ & 398 & 106 & -.89 & .23 & .76 & -1.6 & .67 & -1.9 & .76 \\
\hline
\end{tabular}

